\title{
Comparison of passive haemagglutination test with Widal agglutination test for serological diagnosis of typhoid fever in an endemic area
}

\author{
YM COOVADIA, V SINGH, RH BHANA, N MOODLEY \\ From the Department of Microbiology, Faculty of Medicine, University of Natal and King Edward VIII \\ Hospital, Durban, South Africa
}

SUMMARY A passive haemagglutination test, using sheep red blood cells sensitised with Salmonella typhi lipopolysaccharide, was compared with the Widal test for the serological diagnosis of typhoid fever in an endemic area. The results obtained on sera from 152 patients with bacteriologically confirmed typhoid and 183 patients who did not have typhoid were analysed in terms of sensitivity, specificity, simplicity, and rapidity of the respective tests. The passive haemagglutination test was found to be more sensitive $(80 \%)$ than the $S$ typhi $\mathrm{O}$ antigen $(71 \%)$ but marginally less sensitive than the $\mathrm{H}$ antigen $(82 \%)$ of the Widal test. The false positive rate on control sera was $1.2 \%$ and $6.6 \%$, respectively, for the Widal $\mathrm{O}$ and $\mathrm{H}$ antigens, and $1.6 \%$ for the passive haemagglutination test. Our findings indicate that the passive haemagglutination test is comparable with the Widal test for the serological diagnosis of typhoid fever in endemic areas, but is more simple, rapid, and economic. The passive haemagglutination test may be a useful alternative to the Widal test for the serological diagnosis of typhoid fever in busy microbiology laboratories in areas in which the disease is endemic.

Typhoid fever, which is still a common disease in the Black population of South Africa, does not always present a distinct clinical picture; and other bacterial and even viral infections may mimic its presentation. ${ }^{1}$ Chloramphenicol, a potentially toxic drug, is still considered by many to be the preferred antibiotic for treating typhoid fever. Bacteriological confirmation of clinically suspected typhoid fever remains the most definitive diagnostic procedure but is associated with a delay of 48-72 hours. Laboratory tests, which provide a rapid presumptive diagnosis of typhoid fever allow early and appropriate antimicrobial treatment to be started. The Widal test remains the most widely used serological test for detecting antibodies to Salmonella typhi but has serious shortcomings that have been discussed elsewhere. ${ }^{23}$ This prompted the investigation of other tests for the early and accurate diagnosis of typhoid fever, including counterimmunoelectrophoresis ${ }^{4}$ and enzyme linked immunosorbent assay (ELISA) ${ }^{5}$ for the detection of antibodies and coagglutination tests for detecting

Accepted for publication 23 January 1986 antigen in urine and serum. ${ }^{67}$ None of these tests, however, has gained widespread acceptance in routine microbiology laboratories. In a previous pilot study (abstract presented to South African Society for Microbiology; Second Annual Congress), we evaluated a passive haemagglutination test, using sheep red blood cells sensitised with $S$ typhi lipopolysaccharide and compared it with the Widal, counterimmunoelectrophoresis, and ELISA for the serological diagnosis of typhoid fever. Our preliminary findings suggested that the passive haemagglutination $\frac{T}{O}$ test had distinct advantages over these other tests. In this study we further evaluate the passive hae- $N$ magglutination test and compare it with the Widal test for the serological diagnosis of typhoid fever.

\section{Material and methods}

Serum specimens were obtained from three groups. $\stackrel{\mathscr{\Phi}}{+}$ Group A comprised 152 febrile patients admitted to $\square$ the medical and paediatric wards of King Edward

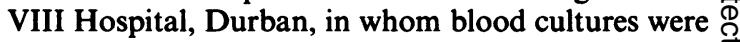
positive for $S$ typhi. Their ages ranged from $10 \stackrel{\mathbb{Q}}{\mathbb{Q}}$ months to 57 years with a mean of 19.5 years. 
Table 1 Anti-S typhi antibody titres in sera of patients and controls detected by passive haemagglutination test

\begin{tabular}{|c|c|c|c|c|c|c|c|c|c|c|c|}
\hline \multirow[t]{2}{*}{ Group } & \multirow[t]{2}{*}{ No } & \multicolumn{10}{|c|}{ No of sera with reciprocal antibody titres of: } \\
\hline & & $<10$ & 10 & 20 & 40 & 80 & 160 & 320 & 640 & 1280 & $\geqslant 2560$ \\
\hline $\begin{array}{l}\text { Typhoid } \\
\text { Non-typhoid fevers } \\
\text { Normal }\end{array}$ & $\begin{array}{r}152 \\
83 \\
100\end{array}$ & $\begin{array}{l}-19 \\
31\end{array}$ & $\begin{array}{r}2 \\
17 \\
21\end{array}$ & $\begin{array}{l}15 \\
23 \\
27\end{array}$ & $\begin{array}{l}14 \\
22 \\
20\end{array}$ & $\begin{array}{r}36 \\
2 \\
1\end{array}$ & 35 & 27 & 9 & 11 & 3 \\
\hline
\end{tabular}

Group B comprised 83 paediatric and adult inpatients with non-typhoid febrile illnesses, including patients with septicaemias due to Haemophilus influenzae $B(\mathrm{n}=5)$, Streptococcus pneumoniae $(\mathrm{n}=6)$, Neisseria meningitidis $(\mathrm{n}=3)$, Strep pyogenes $(\mathrm{n}=1)$, Strep agalactiae $(\mathrm{n}=4)$, Staphylococcus aureus $(\mathrm{n}=7)$, Klebsiella pneumoniae $(\mathrm{n}=1)$, Serratia liquifaciens $(\mathrm{n}=1)$, Salmonella $\mathrm{sp}(\mathrm{n}=3)$, Pseudomonas aeruginosa $(\mathrm{n}=2)$, and Escherichia coli $(n=4)$. Typhoid was excluded in all these patients by repeated blood, stool, and urine cultures. Their ages ranged from 3 months to 65 years with a mean of 23.7 years.

Group C comprised 50 normal, healthy, Black children and 50 healthy Black adults who participated in a hepatitis B survey and whose ages ranged from 6 months to 60 years, with a mean of 24.9 years.

Sera were obtained from the inpatients within 48 hours of admission, and in some of them repeat specimens were obtained after an interval of seven to 10 days. If not tested immediately the serum specimens were stored at $-70^{\circ} \mathrm{C}$ and tested within a week by a technologist experienced in microbiology.

\section{WIDAL AGGLUTINATION TEST}

Tube agglutinations were performed using standard $S$ typhi $\mathrm{O}$ and $\mathrm{H}$ antigen suspensions (Wellcome Diagnostics, England). Serial dilutions of sera beginning at $1 / 10$ were made in physiological saline. Tubes containing antigen and sera were incubated overnight at $45^{\circ} \mathrm{C}$ in a waterbath. Results were expressed as the inverse of the highest dilution showing agglutination.

\section{PASSIVE HAEMAGGLUTINATION TEST}

The method described by Vos et $a l^{8}$ was used with minor modifications. Salmonella typhi lipopolysaccharide (Sigma, United States of America) was dissolved in phosphate buffered saline at a concentration of $1 \mathrm{mg} / \mathrm{ml}$ and boiled for two hours. After cooling 3 volumes of lipopolysaccharide were added to 1 volume of packed and washed sheep red blood cells, and this was then incubated at $37^{\circ} \mathrm{C}$ for 45 minutes. After this coating procedure the sensitised sheep red blood cells were washed three times in phosphate buffered saline and then stored at $4^{\circ} \mathrm{C}$ for up to a week. Each day a fresh $1 \%$ suspension of sensitised sheep red blood cells was made up in phosphate buffered saline and used for the actual test. At the end of the week the stored sensitised sheep red blood cells were discarded and a fresh batch made up.

\section{METHOD OF HAEMAGGLUTINATION}

Fifty microlitres of phosphate buffered saline with $0.5 \%$ bovine serum albumin were added to each of the round bottomed wells of a microtitre plate. Fifty microlitres of a $1 / 5$ dilution of patients' serum that had been heat inactivated at $56^{\circ} \mathrm{C}$ for 30 minutes was then added to wells in rows 1 and 12 . Using a microdiluter, serial two fold dilutions were made from rows 1 to 11 . Fifty microlitres of unsensitised sheep red blood cells was added to wells of row 12 , and $50 \mu$ lof sensitised sheep red blood cells was added to each of the remaining wells. Each assay included positive and negative reference human sera and sensitised sheep red blood cells controls. Plates were incubated for one and a half hours at $37^{\circ} \mathrm{C}$ after which they were examined for haemagglutination. The end point titre was expressed as the inverse of the highest dilution showing haemagglutination.

\section{REPRODUCIBILITY OF THE PASSIVE}

HAEMAGGLUTINATION TEST

The reproducibility of the passive haemagglutination test was assessed by repeating the test on serum specimens that had been stored at $-70^{\circ} \mathrm{C}$ for periods ranging from one to three months.

\section{Results}

Tables 1 and 2 show the antibody titres of patients with bacteriologically confirmed typhoid and those of controls, respectively, using the passive haemagglutination test and the Widal test. On the basis of results obtained on sera from the normal healthy Black subjects a titre of $\geqslant 1 / 80$ was taken as indicating a response to the test antigens of both the Widal $(\mathrm{O}$ and $\mathrm{H})$ and the passive haemagglutination test, respectively.

With the passive haemagglutination test, $\mathrm{O}$ antibody titres of $\geqslant 1 / 80$ were observed in $79.6 \%$ (121 of 152) of sera from patients with typhoid. The false positive rate for sera from the non-typhoid febrile 
Table 2 Anti-S typhi $O$ and $H$ antibody titres in sera of patients and controls detected by Widal test

\begin{tabular}{|c|c|c|c|c|c|c|c|c|c|c|c|c|}
\hline \multirow[t]{2}{*}{ Group } & \multirow[t]{2}{*}{ Antigen } & \multirow[t]{2}{*}{ No } & \multicolumn{10}{|c|}{ No of sera with reciprocal antibody titres of: } \\
\hline & & & $<10$ & 10 & 20 & 40 & 80 & 160 & 320 & 640 & 1280 & $\geqslant 2560$ \\
\hline $\begin{array}{l}\text { Typhoid } \\
\text { Non-typhoid fevers } \\
\text { Normal } \\
\text { Typhoid } \\
\text { Non-typhoid fevers } \\
\text { Normal }\end{array}$ & $\begin{array}{l}\mathbf{O} \\
\mathbf{O} \\
\mathbf{O} \\
\mathbf{H} \\
\mathbf{H} \\
\mathbf{H}\end{array}$ & $\begin{array}{r}152 \\
66 \\
100 \\
152 \\
66 \\
100\end{array}$ & $\begin{array}{r}2 \\
36 \\
44 \\
24 \\
49\end{array}$ & $\begin{array}{r}5 \\
14 \\
29 \\
13 \\
19\end{array}$ & $\begin{array}{r}10 \\
9 \\
18 \\
10 \\
11 \\
10\end{array}$ & $\begin{array}{r}27 \\
2 \\
9 \\
18 \\
12 \\
15\end{array}$ & $\begin{array}{r}30 \\
2 \\
9 \\
3 \\
7\end{array}$ & $\begin{array}{r}13 \\
1\end{array}$ & 20 & 13 & 10 & 14 \\
\hline
\end{tabular}

patients was $2 \cdot 4 \%$ ( 2 of 83$)$, and $1 \%$ (1 of 100$)$ on sera obtained from the 100 normal healthy subjects.

Using the Widal test, $71 \cdot 1 \%$ (108 of 152 ) of patients with typhoid confirmed by culture had $\mathrm{O}$ agglutinin titres of $\geqslant 1 / 80$, and $81.6 \%$ (124 of 152$)$ had $\mathrm{H}$ agglutinin titres of $\geqslant 1 / 80$. In the non-typhoid febrile patients $\mathrm{O}$ and $\mathrm{H}$ agglutinin titres of $\geqslant 1 / 80$ were observed in $3 \%$ and $6 \%$ of sera, respectively. None of the sera from the normal healthy subjects gave $O$ agglutinin titres of $\geqslant 1 / 80$, and only $7 \%$ ( 7 of 100 ) were positive at this titre for the $\mathrm{H}$ agglutinins. Table 3 summarises the overall sensitivity and specificity of the passive haemagglutination test and the Widal test ( $O$ and $H$ antigens).

Paired serum specimens taken one week apart were obtained from 20 patients with typhoid confirmed by culture. None of these paired sera showed a four fold rise in titre by either the passive haemagglutination test or the Widal test.

The results obtained on stored sera showed that the passive haemagglutination test had good reproducibility. Of the 30 positive sera that had repeat tests performed on them over three months, no difference was observed in 24 specimens, a one tube difference in five specimens, and a two tube difference in one.

The technologist reading the two tests found that the interpretation of positive and negative reactions was easier with the passive haemagglutination test than with the Widal test. In addition, the use of microtitre plates for the passive haemagglutination test facilitated the testing of large numbers of specimens over a short period. The Widal test, by contrast, took much longer to set up and was also calculated to be far more expensive than the passive haemagglutination test for a comparable number of tests.

\section{Discussion}

At the King Edward VIII Hospital, Durban, 40 to 60 patients with typhoid confirmed by culture are treated each month. The microbiology laboratory receives an average of 600 serum specimens per month for the serological confirmation of suspected typhoid fever. We therefore felt there was a need for a serological test which would be simple, sensitive, specific, and rapid. The Widal test, in our hands, was found to be relatively expensive in terms of reagents, materials, and technologists' time, and an additional disadvantage is that the final results were only available after overnight incubation: Tsang $e t a l^{4}$ using a veronal buffer extract of $S$ typhi, obtained excellent results with counterimmunoelectrophoresis, which showed a sensitivity of $96 \%$ and a specificity of $100 \%$ for the serological diagnosis of typhoid. Counterimmunoelectrophoresis, however, also has certain disadvantages in that it requires the use of expensive electrophoretic apparatus, in addition to not providing quantitative results with which to compare serial serum specimens. Beasely $e t a^{5}$ used a titre of more than $1 / 500$ as positive and detected IgG antibodies by ELISA in at least one of the paired sera from all 81 confirmed cases of typhoid fever. False positive results were observed in $8.7 \%$ ( 2 of 23 ) of sera from patients with non-typhoid illnesses. Although ELISA meets the requirements of sensitivity and simplicity, a certain amount of technical expertise is still required for initially setting it up. In addition, the test is not very suitable for processing small numbers of specimens on a daily basis, and the need for relatively expensive reagents may also be a disadvantage for small laboratories. In a previously conducted pilot

Table 3 Results obtained by passive haemagglutination test and Widal test on sera from different groups of patients

\begin{tabular}{|c|c|c|c|c|}
\hline \multirow{3}{*}{ Group } & \multicolumn{4}{|c|}{ No (10) with antibody titres of $\geqslant 1 / 80$ by: } \\
\hline & \multirow[t]{2}{*}{ No } & \multirow{2}{*}{$\begin{array}{l}\text { Passive } \\
\text { haemagglutination } \\
\text { test }\end{array}$} & \multicolumn{2}{|l|}{ Widal } \\
\hline & & & $O$ & $\boldsymbol{H}$ \\
\hline $\begin{array}{l}\text { Typhoid } \\
\text { Non-typhoid fevers } \\
\text { Normal }\end{array}$ & $\begin{array}{r}152 \\
83 \\
100\end{array}$ & $\begin{array}{c}121(79 \cdot 6) \\
2(2 \cdot 4) \\
1(1)\end{array}$ & $\begin{array}{l}108(71 \cdot 1) \\
2 / 66^{*}(3) \\
0\end{array}$ & $\begin{array}{l}124(81 \cdot 6) \\
4 / 66^{*}(6 \cdot 1) \\
7(7)\end{array}$ \\
\hline
\end{tabular}

*Only 66 specimens tested. 
study in this laboratory we observed sensitivity rates of $93 \%$ and $53 \%$, respectively, for ELISA and counterimmunoelectrophoresis and specificity rates of $56 \%$ and $84 \%$, respectively (abstract, South African Society for Microbiology; Second Annual Congress).

To our knowledge, haemagglutination tests, despite their greater sensitivity and versatility compared with direct agglutination tests, have not yet been used for the serodiagnosis of typhoid fever. In this study the passive haemagglutination test was more sensitive $(80 \%)$ than the Widal $O$ antigen (71\%) but marginally less sensitive than the $H$ antigen $(82 \%)$. The specificity of the passive haemagglutination test $(98.4 \%)$ was similar to that of the Widal $\mathrm{O}$ antigen $(98.8 \%)$ but superior to the Widal $\mathrm{H}$ antigen $(93.4 \%)$.

The passive haemagglutination test does not require any sophisticated equipment, provides clearly visible positive and negative results, is an extremely easy test to set up, and the use of microtitre plates facilitates the testing of large numbers of specimens in a single run. These qualities make this test especially suited to small laboratories in areas in which typhoid is endemic, especially in Third World countries.

The finding in this study that the Widal $\mathrm{H}$ agglutinin was more sensitive than the $O$ agglutinin for the diagnosis of typhoid agrees with that reported by Wicks et al, ${ }^{9}$ Brodie, ${ }^{10}$ and Somerville et al ${ }^{11}$ but differs from that reported by Schroeder, ${ }^{2}$ Senewiratne et $a l,{ }^{3}$ Pang and Puthucheary, ${ }^{12}$ and Shehabi. ${ }^{13}$ In the opinion of Schroeder ${ }^{2}$ the $\mathrm{H}$ antigen titre is of little value in diagnosing typhoid fever, because it is extremely variable and can rise as a non-specific response to other infections. We found that the $\mathbf{H}$ agglutinin had a specificity of $93 \%$ for the diagnosis of typhoid fever. The true value of the $\mathrm{H}$ antigen titre, therefore, remains to be determined.

The well established criterion for serological diagnosis (showing a four fold rise in titre) was not valid in this study, which is in keeping with the observation of others. ${ }^{111}$ These findings can be explained by the fact that many of our patients presented late in the course of their illness and therefore would have attained peak antibody titres at the time of admission. Alternatively, some of the patients might have had a response as a result of previous exposure in areas endemic for typhoid fever. Although use of the typhoid vaccine also makes the serological interpretation of the Widal test difficult, this is not a major problem in South African Blacks, because very few are vaccinated against typhoid. We also found that about $10 \%$ of patients with typhoid confirmed by culture were serologically negative by all three tests (passive haemagglutination test and Widal $\mathrm{O}$ and $\mathrm{H}$ antigens), which confirms that culture remains the most definitive diagnostic procedure for typhoid.

In conclusion, our findings indicate that the passive haemagglutination test is comparable with the Widal test for the serological diagnosis of typhoid fever but offers the advantages of simplicity, rapidity, economy, and flexibility for handling small or large numbers of specimens. The passive haemagglutination test may, therefore, prove to be a useful alternative to the Widal test, particularly in smaller laboratories in areas endemic for typhoid fever.

\section{References}

${ }^{1}$ Levine MM, Grados O, Gilman RH, Woodward WE, Solisplaza R, Waldman W. Diagnostic value of the Widal test in areas endemic for typhoid fever. Am J Trop Med Hyg 1978;27: 795-800.

${ }^{2}$ Schroeder SA. Interpretation of serologic tests for typhoid fever. JAMA 1968;206:839-40.

${ }^{3}$ Senewiratne B, Senewiratne K. Reassessment of the Widal test in the diagnosis of typhoid. Gastroenterology 1977;73:233-6.

4 Tsang RSW, Chau PY. Serological diagnosis of typhoid fever by counterimmunoelectrophoresis. Br Med J 1981;282:1505-7.

${ }^{5}$ Beasley WJ, Joseph SW, Weiss E. Improved serodiagnosis of salmonella enteric fevers by an enzyme-linked immunosorbent assay. J Clin Microbiol 1981;13:106-14.

${ }^{6}$ Rockhill RC, Rumans LW, Lesmans M, Dennis DT. Detection of S typhi D V1 and d antigens by slide coagglutination in urine from patients with typhoid fever. J Clin Microbiol 1980;11: 213-6.

${ }^{7}$ Sivadasan K, Kurien B, John TJ. Rapid diagnosis of typhoid fever by antigen detection. Lancet 1984;i:134-5.

${ }^{8}$ Vos JG, Buys J, Hanstede JG, Hagenaars AM. Comparison of enzyme-linked immunosorbent assay and passive haemagglutination method for quantification of antibodies to lipopolysaccharide and tetanus toxoid in rats. Infect Immun 1979;24:798-803.

${ }^{9}$ Wicks ACB, Cruickshank JG, Musewe N. Observations on the diagnosis of typhoid fever in an endemic area. $S$ Afr Med $J$ 1974;48:1368-70.

${ }^{10}$ Brodie J. Antibodies and the Aberdeen typhoid outbreak of 1964. 1. The Widal reaction. J Hyg 1977;79:161-80.

${ }^{11}$ Somerville PC, Lewis M, Koornhof HJ, Alberts M, Alberts HW, Raymond $\mathbf{R}$. The Widal test in the diagnosis of typhoid fever in the Transvaal. S Afr Med J 1981;59:851-4.

${ }^{12}$ Pang T, Putchucheary SD. Significance and value of the Widal test in the diagnosis of typhoid fever in an endemic area. $J$ Clin Pathol 1983;36:471-5.

${ }^{13}$ Shehabi AA. The value of a single Widal test in the diagnosis of acute typhoid fever. Trop Geogr Med 1981;33:113-6.

Requests for reprints to: Dr YM Coovadia, Department of Microbiology, Faculty of Medicine, University of Natal, PO Box 17039, Congella, Durban, South Africa. 